heterozygote is intermediate. Experimental difficulties are considerable. The plants are large, the flowers are not entirely self-fertilised, and some of the characters fluctuate considerably. Numerous pests attack the plants, including aphides, boll worm, and the cotton stainer bug, while two fungi, the "sooty mould" and "sore-shin," do great damage. An advantage, however, is that the cotton plant can be grown as perennial by simply cutting it back; in this way a further supply of seed from a particular plant can always be obtained if necessary.

Bees appear to be the chief agents in effecting crosspollination, and they have to be excluded by mosquito nets covering the whole plant; there appears to be no wind-fertilisation. Before these nets were used, the preparation of self-fertilised seed was laborious and uncertain. Tissue-paper bags were employed for separate flowers, but a large proportion of the bagged flowers were shed. Now the operation is simplified. The flowers are castrated at 4 a.m. and cross-pollinated at 9 a.m. No bags are necessary if the other open flowers under the net are removed, except, of course, to cover the flower from the plant which is to be employed as the male parent.

The results are worked out in detail for a number of unit characters, and are plotted on curves. The data thus obtained are not only interesting in themselves as a study of a Mendelian problem, but are of distinct practical value for the cotton breeder.

Mr. Balls also writes on the general position of the cotton crop in Egypt, and gives a number of interesting historical details. It is not certain how or when cotton was first cultivated in Egypt. The old mummy cloths are of flax. Apparently no distinct allusion to cotton occurs until the time of Pliny, and there is nothing to show that cotton was cultivated before $200 \mathrm{BrC}$. No definite historical account can be given until the time of Jumel, a French engineer who, in the early years of the last century, recognised the possibilities of Egyptian cotton and made plans for extending and improving its cultivation. Importation of Sea Island cotton began in 1822 and went on for many years; Mr. Balls's view is that the present Egyptian cottons are hybrids between the brown-linted tree types associated with Jumel and Sea Island cotton. He further thinks that, for the future, it is necessary to evolve strains which mature early and are therefore not likely to suffer from the boll-worm, and which yield heavily, so as to compensate for the decreased production per acre which is now setting in.

This falling off in productivity makes a very pretty problem unlike any we know of elsewhere. Fifteen years ago the yields ran about 5.5 cantars per feddan; of late years they are only 4.5 . There are, of course, many conceivable explanations duly set out in the report of the commission in the present volume and meriting further examination, but it is suggested that part of the trouble arises from a rise in the subsoil water following on the rise brought about in the Nile by the barrage schemes. On this question $\mathrm{Mr}$. Lucas has something to say in the Cairo Scientific Journal. He tabulates the minimum water-level in certain wells, and shows that in these cases there has been a rise of more than $x$ metre since 1894 . Other factors have to be taken into consideration, and many further measurements will be required, but the scientific interest and practical importance of the problem can hardiy be overrated.

Mr. Hughes gives an account of manurial trials on cotton, and we are pleased to see that he gives full mechanical and chemical analyses of the soils on lines accepted in Great Britain. A considerable amount of trouble is involved, but the results are of much wider value in consequence. Mr. Willcocks describes the insects injurious to stored grains, seeds, \&c. In the Cairo Scientific Journal Mr. Fletcher describes an experiment in which maize was grown for ten days in soils heated, respectively, to $95^{\circ} \mathrm{C}$. and $170^{\circ} \mathrm{C}$., and which he considers inconsistent with the work of Russell and Hutchinson. Mr. Fletcher accepts Whitney's hypothesis that soils contain a toxin injurious to plants, but put out of action by heat, an hypothesis much too controversial to be discussed here. No acrount appears to have been taken of the marked chemical decomposition of soil substances at the high temperature of the experiment.

No. 2 I 28 , voL. 84$]$

\section{SCIENCE IN BENGAL.}

THE Journal and Proceedings (new series) of the Asiatic Society of Bengal has become a veritable miscellanya very doubtful improvement upon the old arrangement followed by the Society, of publishing papers on philology and archæology, natural science, and ethnology, in three distinct and independent " parts," and of relegating matters of domestic and colloquial interest to the Proceedings.

The latest issues (Nos. 5-II of vol. iv.) include thirty papers, in which Hindu mythology, numismatics, natural history both of the formal and of the discursive kind, archæology, geography, higher mathematics, lists of Oriental MSS., botany, epigraphy, and Indian history keep the strangest and most bewildering company with fragments of chemistry, philology, and geology, and with obituary notices and other domestic records.

Many of the papers deal with speculations rather than with matters of verifiable fact, and of these one of the most reasonable and most generally interesting is that by Mr. G. R. Kaye, on the use of the abacus in ancient India. The author examines, and expresses himself far from satisfied with, the evidence offered in support of the belief that the abacus was used in India in ancient times; and he is not at all disposed to accept without question the view that the Arabs borrowed their notation, which forms the basis of the science of arithmetic, from the Hindus.

The noteworthy papers on natural science are three in number. In one, Dr. N. Annandale describes a recent Himalayan species of a Psychodid fly of the genus Diplonema, a genus that " appears to have been known hitherto from three "Tertiary species which occur in Baltic amber and from one Quaternary form in fossil copal." Another paper, by Mr. $\mathrm{P}$. Bruhi, on recent plant immigrants into Bengal and Bihar, is a laborious compilation of considerable value, although, as the author includes cultivated plants as well as weeds, the title is a little disappointing ; 234 phanerogams are enumerated and classified according to their systematic position and their land of origin, the result showing that 54.7 per cent. of them have been derived from America. Of these 234 species, however. only thirty-seven are entirely wild, and so are true, unassisted (or, at any rate, not deliberately introduced) immigrants; all the others are either cultivated or can be traced to cultivation. A third paper, by Colonel Prain and Mr. Burkill, describes seventeen new species of yams from China and neighbouring countries to the south, the descriptions, which are in Latin, being models of clearness and concisencss.

The twenty-first instalment of the late Sir George King's "Materials for a Flora of the Malayan Peninsula" is happily distinguished by appearing as an independent "extra number" of the old series of the Society's journal. It treats of the Gesneraceæ and Verbenacer. Of the former order, I3 I species, distributed in twenty genera, are described by $\mathrm{Mr}$. H. N. Ridley; of the latter order, seventy-two species, belonging to fifteen genera, are dealt with by Mr. J. S. Gamble.

We have also received Nos. 5-9 of the second volume of the new Memoirs of this society.

No. 5 of these is a most learned and interesting treatise (which is to be continued) on Mundari poetry, by Father J. Hoffmann. The Mundas are one of the aborigina tribes of Central India, and a large remnant of them is isolated in the hills of Chota Nagpur. "Their world is a narrow circle of villages hidden away in forest-clad mountains .... and they are quite content to leave... its wonders to such races as may care for them. Their only desire... is to be left alone." They are entirely illiterate, and know nothing about any alphabet. If they did, one would suggest that the sixteenth ode of the second book of Horace might be translated into their language as a good reflection of their views of life; but their own poetry, which is meant to be sung, does not touch the skirts of divine philosophy: it deals with the simplest of perennial themes, such as first love, friendship, maiden vanity, the pleasures of the chase, and the goodness of the good old customs, or, on the other hand, blighted affection, the nangs of hunger, and the terrors of the jungle. According to Father Hoffmann, their simple lyrics 
are unrhymed, and have no pronounced rhythm, except such as is imparted by the singer; and they consist for the most part of repetitions of some simple idea, but are saved from monotony by a tricky use of synonym and metaphor. As the vocabulary is limited, the Munda poet uses the utmost freedom in detaching a required word from its associations; for instance, in order to harp upon the idea of the perfume of flowers, the word that in ordinary conversation implies an ancient and fish-like smell may be used as a synonym with perfect propriety. But this poetic licence never breaks the bounds of decorum: "Of the hundreds of songs which, after the day's work, resound over the whole country, evening after evening, not one is defiled by a lewd expression, or even by an indecent allusion.'

No. 8 of these Memoirs is entitled "A Monograph of Sea-snakes," and its author would have done better had he considered that in this very fallible world nothing is ever gained by labouring to expose the mistakes-or supposed mistakes-of fellow-workers. To read this pretentious "monograph," one might suppose that the British Museum Catalogue of Snakes, the author of which is persistently gleeked and galled at throughout, was hardly worth the paper it is printed on. No doubt there may be errors in the catalogue, as there are in all the works of mortal men; but even were the errors great and manifoldand no one who uses the catalogue considers this to be the case-the work would still stand out as a comprehensive and critical account of our knowledge of the Ophidia, and a well-arranged storehouse of fact, to which all after-workers must be indebted, whether they choose to acknowledge their debt or not. So that when the author of this monograph states that his "views are substantially different from those held by "Professor' Boulenger" (the distinguished begetter of the British Museum Catalogue), and further solemnly announces that "there are discrepancies between Mr. Boulenger's work and mine affecting questions of actual fact," the most easy-going critic is roused to attention.

The shattering "discrepancy of fact" turns in the main upon the question whether the posterior maxillary teeth of certain sea-snakes are grooved or not. The British Museum Catalogue recognises the genus Hydrophis as distinct from the genus Distira, because in the former genus the posterior maxillary teeth are not grooved as they are in the latter genus; but to the author of this monograph, using "a new lens of the very highest power and quality specially recommended for this work," it "became clearly revealed" that the posterior maxillary teeth in Hydrophis are "all grooved." In any case, the matter is of no very great importance, as every naturalist understands that the limits between species and genera are often not very sharply defined; but to test the case we removed the poison-fang and one of the posterior maxillary teeth of a well-preserved and authentic spirit-specimen of Hydrophis latifasciatus, and examined them side by side, not indeed with any " patent duuble million magnify in" gas microscopes of hextra power" such as Mr. Sam Weller demanded in order to see through a flight of stairs and a deal door, but with an ordinary microscope. In the poison-fang the poison-canal is as plain as a diagram; in the small posterior tooth there is no trace whatever of any groove.

If, instead of holding up the British Museum Catalogue to reprobation, and adding grievous burdens to terminology, the author had given us some facts about the anatomy of sea-snakes, and had summarised what is known about the habits, food, and enemies of these animals, and the naturc and mode of action of their venom, his work might have approached the standard of a monograph. As it stands, it is merely what is known as a revision of the subfamily-and an incomplete revision, because, among other things, the several genera are not fully defined, and are not properly referred to their respective authors.

We cannot leave these Memoirs without a short reference to No. 9, which contains a "Polyglot List of Birds in Turki, Manchu, and Chinese," by Dr. E. D. Ross. The author disclaims any acquaintance with ornithology, and apologises for undertaking such work "with nothing but linguistic equipment." The paper, which, with indices, sccupies more than Ioo pages, is divided into " Part i.,
Large Birds," for which the "generic" name is Qus, and "Section ii.,. Small Birds," for which the general name is Qucqac; 360 birds are included; some of them are specificaliy identified, others are identified in a general way, while others are merely treated after the manner of the commentator. An illustration of each of the three methods will show how far this dish of literary minutalia is likely to be of service to an ornithologist.

3o. Qu:? The Cormorant: Manchu, Kotan; Chinese, Tao Ho. The 'Mirror' says : 'It somewhat resembles the wild swan and is grey in colour. Its beak is wide and its crop large. It fills its crop with water which it pours into rat-holes, and having thus driven out the rats eats them.' I am in doubt whether the swan or cormorant is intended here. $Q u$ is the common Turki name for a swan.",

" I79. Aqis Cikdaci: The Chough: Pyrrhocorax graculus: Manchu, Cinjiri; Chinese, Liao ko [Giles's Dict., the blue grackle]. 'The 'Mirror' says: 'Colouration violet; red beak parting on the top of the head. A skilful singer with a very clear voice.' ",

"336. Ding ding Qucqac: A species of wagtail: Manchu, Tukiyeri cecike; Chinese, Yao t'un ch'iao. The 'Mirror' says: 'Over the eyelids are long ash-coloured feathers looking like eyebrows; short tail; always struts when walking."

Many other fearful wildfowl are exhibited, and all are fitted with tags of comment and reference, some of which call to mind the notes to Thackeray's delightful paradoy "Timbuctoo."

\section{AUSTRALIAN AND ARGENTINE BIOLOGY.}

THE third number of the Memoirs of the National Museum of Melbourns is devoted to descriptions by Messrs. Baldwin Spencer and J. A. Kershaw of remains of subfossil emeus and marsupials from King Island, Bass Strait, and, in a second paper, to a review of the existing species of wombat. As regards emeus, the authors find that Kangaroo Island, King Island, and Tasmania were severally inhabited by species distinct from Dromaeus novae-hollandiae of the mainland. Both the Kangaroo Island $D$. peroni (ater) and the King Island $D$. minor were darker than the mainland bird, the first being distinguished from the second by its less robust build. The Tasmanian emeu, which survived in numbers until at least as late as 1840 , is still insufficiently described, but appears to have differed in colour from each of the other three species, and also laid eggs of a distinctive character.

With the exception of a Dasyurus, the marsupials from King Island are identified with existing species.

Turning to wombats, the authors state that the first specimen known to Europeans was secured on Clarke Island, Bass Strait, in 1797 (not by Bass), and taken alive to Sydney, this forming the type of Shaw's Didelphys ursina. All the early examples of wombats came, in fact, from the islands in Bass Strait, and the identification of the Tasmanian animal with the Bass Strait Phascolomys ursinus is shown to be erroneous. In addition to skulls and bones, it appears to be now represented in collections only by a couple of skins recently secured on Flinders Island, where it still survives. The Tasmanian species, for which the authors propose the name $P$. tasmanicnsis, is intermediate in size between the large mitchelli and the smaller ursinus, but agrees in shape with the forrer; its general colour is grizzled grey, with light hairs inside the ears.

In the course of a long paper on the birds of the East Murchison district, published in the April number (vol. ix. part iv.) of the Emu, Mr. F. L. Whitlock gives an account of his discovery of the playing-grounds and nests of the yellow-spotted bower-bird (Chlamydodera guttata), illustrated by photographs. A peculiar feature of the species is that at the commencement of the breeding season several individuals sometimes resort to the same play-ground, where the adult males make a nuptial display. The dimensions of one play-ground were 7 by 5 feet. The foundation was a mass of twigs, which raised the floor of the inverted arch about 6 or 8 inches above the general level of the ground, the walls of the arch being some 